\title{
RUANG KESEHARIAN SEBAGAI REPRESENTASI IDENTITAS PERSONAL
}

\author{
Sandi Jaya Saputra \\ Universitas Padjadjaran
}

\begin{abstract}
ABSTRAK
Dalam artikel ini penulis membedah keseharian ruang personal dengan mengunakan medium fotografi, yaitu objek kamar kos penulis. Tujuannya adalah untuk merepresentasikan identitas dan ruang penulis dari realitas keseharian, dan menghubungkannya dengan narasi modernitas. Identitas dalam ruang dibentuk oleh struktur dan superstruktur. Struktur dipahami sebagai sesuatu hal yang remeh temeh tetapi material, yaitu benda-benda keseharian yang akrab dengan penulis. Sementara itu, super struktur dipahami sebagai wacana yang ideologis dan abstrak, sebagai penggambaran dari ruang ketiga seperti kusen, tembok dan lainnya. Dalam membedah identitas dan ruang ketiga, serta hubungannya dengan struktur dan super struktur, penulis menggunakan pendekatan foto dokumenter. Pendekatan dalam foto dokumenter mampu mengurai indeks akan sebuah realita mengenai keseharian dalam kamar kos penulis. Dalam artikel ini, penulis menunjukan relasi praktik keseharian yang remeh temeh dengan wacana besar modernitas. Atas kondisi tersebut, diharapkan adanya proses nyata yang saling berhubungan antara penulis dengan medium fotografi dan masyarakat. Artikel ini bertujuan untuk mengeksplorasi representasi konteks ruang keseharian secara ideologis, dengan membedah berbagai komponen sebagai denotasi pada lapisan pertama untuk menafsirkan kenyataan. Pada langkah selanjutnya, penulis membedah lapisan dalam representasi visual sebagai konotasi dan mitos. Seluruh proses ini akan dilakukan menuju pengelolaan ruang keseharian sebagai representasi identitas pribadi.
\end{abstract}

Kata-kata Kunci: Foto dokumenter, fotografi, identitas, personal, ruang ketiga, struktur dan super struktur

\section{DIURNAL SPACE AS REPRESENTATION OF PERSONAL IDENTITY}

\begin{abstract}
In this article, Author will discuss about my personal life, particularly my own dormitory room. The objective of this article is representing the identity and space of my dormitory room in daily existence, and its relation with modernity narration. Identity and space are developed by structure and super structure. Structure coined as some things insignificant, yet being the basic needs in my daily life. Whilst super structure is well known as the ideological and abstract matter as the portrayal of the third space, such as sills, walls, etc. In exposing the identity and space, and its relation with structure and super structure, Author employ the documentary photography approach. This method was trusted to be the most suitable way to uncover the issue, since its capabilities to analyze the index of daily existence especially in my dormitory room. This articles illustrate the relation of insignificant daily routine and the big narration of modernity. Therefore, it has been expected to enclose the factual process transmitted between artists and society. This article aims to explore the representation of diurnal context ideologically, by dissecting various components as denotation on the first layer to interpret the reality. On the next step, the writer dissects the inner layer of visual representation as of connotation and myth. This whole process will be conducted towards the managing of diurnal space as representation of personal identity.
\end{abstract}

Keywords: Photo documentary, art photography, identity, daily life, personal, third space, structure and super structure

Korespondensi: Sandi Jaya Saputra, S.I.Kom., M.Sn, Program Studi Jurnalistik Fakultas Ilmu Komunikasi, Universitas Padjadjaran, Jl. Raya Bandung-Sumedang Km.21. Email: sandijayasaputra@yahoo.co.id 


\section{PENDAHULUAN}

Keseharian, menurut berbagai teori dan pemahaman, bukan sesuatu yang asing dalam kehidupan masyarakat global dewasa ini. Menurut Karl Marx mengenai basis dan super struktur, yang selanjutnya menjadi dasar pemikiran Roland Barthes dimana basis menjadi 'denotasi' dan super-struktur adalah 'konotasi' dan 'mitos', bagaimana seseorang menjadi seperti hari ini adalah karena konstruksi dari struktur dan super struktur tersebut. Lingkungan struktur manusia modern adalah wilayah personal tetapi material, seperti halnya Marxist memahami base-structure yang terdapat faktorfaktor material dari relasi produksi. Penulis melihat persoalan ini dari pola konsumsi seseorang, seperti apa yang melekat pada tubuhnya, yang akhirnya dapat mengidentifikasi karakter orang tersebut. Sementara wilayah super struktur adalah wilayah yang ideologis, seperti ide atau pemikiran seseorang disebabkan adanya perubahan di masyarakat akibat modernisasi yang diikuti dengan perkembangan media masa (Mahareruaji, 2014: 45).

Pemaknaan wacana keseharian dapat lahir melalui proses penghayatan dan pengalaman langsung yang tidak metodis dan tidak sepenuhnya rasional, serta mengandung ambivalensi dan dilema. Keseharian pada narasi kecil memiliki kecenderungan atas sesuatu yang gampang dilupakan dan tidak dianggap penting dalam rutinitas, yang kemudian hilang dan mengalir tidak bersisa. Akan tetapi, tanpa disadari selalu diulang, bahkan menjadi hal rutin yang mengalahkan aktivitas dalam narasi besar. Maka dari itu, keseharian yang selalu luput dari perhatian adalah keseharian yang 'remeh temeh'. Apabila dihubungkan dengan artikel Sugiharto (2013: 1), keseharian merupakan "pengalaman langsung hari demi hari, realitas intim yang saat demi saat langsung kita jalani."

Tidak dapat dipungkiri, keseharian pada umumnya, yaitu narasi kecil sangat terpengaruh oleh narasi besar modernitas. Konsep keseharian dalam narasi kecil yang penulis maksud adalah sebuah kebiasaan dalam keseharian yang tidak bernilai dan tidak signifikan dalam kehidupan keseharian, seperti objek-objek yang penulis abadikan dalam foto pembahasan.

Tidak terpikirkan sebelumnya bahwa penulis akan mengangkat kamar kos penulis sebagai objek. Hal ini muncul sebagai salah satu bentuk kegelisahan personal penulis yang lahir dari pola konsumsi. Kemudian kegelisahan ini berkembang menjadi sebuah pemahaman dari apa yang penulis pikirkan, mengenai sebuah sistem yang kompleks dari tatanan sosial masyarakat.

Judul Ruang Keseharian sebagai Representasi Identitas Personal merupakan penegasan mengenai kegelisahan dalam melihat realita yang sangat intim dengan penulis. Penulis membedah cara pandang personal sebagai produk kolektif, merupakan representasi kamar kos penulis yang disajikan dengan mempermasalahkan keseharian penulis dalam kamar kosnya. Hal ini berkaitan dengan pengalaman penulis tentang konstruksi lingkungan personal dan lingkungan sosial yang mempengaruhi penulis saat ini, dengan meminjam segala bentuk dan objek yang ada dalam kamar penulis. Penulis menganalogikan super struktur melalui sekat-sekat kamar seperti tembok, kusen, dan objek lainnya digambarkan secara lebih abstrak. Penulis menekankan pada objek-objek yang memiliki nilai kedekatan dalam keseharian penulis. Penentuan objek dalam setiap frame merunut pada pertimbangan personal penulis yang 'dirasa' memiliki kedekatan dengan penulis dengan menggambarkan struktur dan super struktur tersebut bekerja di wilayah personal penulis. Pada titik ini penulis sadar bahwa kamar kos adalah ruang di mana identitas penulis terhadirkan kembali menjadi sosok global, maka pembacaanya menarasikan relasi-relasi keseharian penulis dalam wacana modernitas.

\section{METODE PENELITIAN}

Di era fotografi kontemporer, narasi-narasi besar tentang kehidupan modern dan berbagai problematikanya selalu menjadi subjek yang menarik. Meskipun demikian, penulis bertujuan mengkaji narasi lain, yaitu narasi kecil di balik kehidupan modern saat ini. Pemilihan subjek ini penulis pandang sangat relevan dengan kondisi Indonesia hari ini. Di satu sisi, perkembangan menjadi suatu negara modern dan maju terus berjalan, tetapi di sisi lain ada persoalanpersoalan yang seringkali luput dari pandangan sebagai manusia modern, yaitu keseharian yang penulis sebut wilayah struktur atau sesuatu yang 'remeh temeh' tetapi material.

Merujuk pada objek penelitian yang 
berjudul Ruang Keseharian Sebagai Representasi Identitas Personal ini adalah proyek mengenai keseharian penulis dalam kamar kos. Bagaimana realita kamar dan objek-objek yang berada dalam kamar penulis dipindahkan ke medium representasi, yaitu fotografi. Teori Roland Barthes banyak menjadi rujukan apabila membicarakan tentang representasi yang representasinya merujuk kepada proses realitas dan disampaikan dalam komunikasi, via katakata, bunyi, citra, atau kombinasinya (Fiske, 2004: 282). Representasi juga disebut sebagai cara bagaimana media menginterpretasikan dunia, atau realitas eksternal lainnya (Rayner, 2001: 63). Trifonas menyebutkan representasi sebagai wahana yang dengannya dua hal yang tidak berkaitan dipersatukan untuk mengacu pada sebuah konsep (Trifonas, 2003: 63). Pada dasarnya pandangan representasi ini memiliki semacam korespondensi dengan sesuatu yang direpresentasikan.

Untuk menentukan bagaimana representasi dalam mempersoalkan kamar kos penulis pada judul Ruang Keseharian Sebagai Representasi Identitas Personal adalah seperti halnya yang diungkapkan Barthes bahwa kehadiran foto dalam sebuah berita atau iklan tidak lebih dari sekedar semacam indeks atau bahan untuk menghilangkan suasana membosankan, lebih lanjut foto sudah dipandang sebagai realitas itu sendiri sehingga orang tidak perlu mempersoalkan lagi. Kebiasaan tidak mempersoalkan inilah yang justru dipersoalkan oleh Barthes. Barthes berpendapat bahwa foto dapat membantu untuk mengembangkan subjektivitas manusia dengan "membacanya" (Sunardi, 2004: 163-164).

Wacana keseharian dalam karya penulis adalah representasi identitas dalam keseharian penulis di dalam kamar kos, wacana merupakan salah satu kata kunci dalam pendekatan-pendekatan kontemporer, terutama postrukturalisme. Istilah wacana ini juga sering disebut dengan teks dan diskursus. Secara khusus, definisi wacana mengacu pada pernyataan Michel Foucault (1972: 53) yaitu suatu sistem pernyataan yang di dalamnya dunia dapat diketahui, atau secara spesifik perangkat ide untuk mengetahui objek tertentu. Foucault sendiri merupakan tokoh postrukturalisme. Dua metode yang Foucault tawarkan dalam pembongkaran struktur kekuasaan dan pengetahuan adalah metode arkeologi dan genealogi. Metode pertama dilakukan dengan melalui penggalian (excavation) terhadap masa lalu, sedangkan metode yang kedua mencoba mencari kontinuitas sekaligus diskontinuitas historis objek. Menurut Foucault, objek kajian yang disebutkan disebut arsip, seperangkat wacana yang diungkapkan secara aktual, baik secara ditulis, disusun, diucapkan, dan diungkapkan kembali, maupun ditransformasikan. Wacana identitas dalam kamar kos penulis menjadi kontekstual apabila dihubungkan dengan wacana seni kontemporer, identitas dalam kamar kos menjadi penting dibaca karena identitas tidak terlepas dari konstruksi antara struktur dan super struktur, wacana identitas dalam Ruang Keseharian Sebagai Representasi Identitas Personal menjadi baru karena menjungkir balikkan identitas. Penulis mencoba menghadirkan kemungkinan baru, yaitu bagaimana identitas dalam kamar kos menjadi ruang baru atau ruang ketiga dalam wacana posmodern.

Penulis menggunakana pendekatan foto dokumenter dalam melihat representasi Ruang Keseharian Sebagai Representasi Identitas Personal. Hal tersebut karena foto dokumenter secara penggambaran lebih dekat dengan realita itu sendiri, yaitu keseharian. Keseharian yang banal seolah trivial, terlihat menyimpan misteri yang perlu disingkapkan. Hal ini seperti yang dilakukan Sherlock Holmes yang membuka banyak fakta mengejutkan dibalik hal-hal yang ambivalensi dan dilemma.

Dalam hal ini dapat dikatakan bahwa fotografi dokumenter yang beberapa waktu lalu dipandang sudah usang di dalam seni rupa kontemporer justru sedang mengalami kebangkitan kembali (Demos 2006: 6) dalam Vitamin $\mathrm{Ph}$. Karakter foto dokumenter terlihat lebih 'demokratis' karena secara penggambaran tidak terlihat menggunakan teknik yang canggih dan memiliki kecendrungan lebih 'natural' layaknya sebuah foto yang banal. Sebut saja Alfred Stieglitz yang pada masa awal-awal fotonya masih menggunakan pendekatan victorian untuk diakui dalam medan sosial seni. Karyanya yang dapat diapresiasi medan sosial seni pada masa itu adalah karya-karya yang banal dan menjadi cikal bakal foto dokumenter dalam dunia seni rupa saat ini.

Pendekatan foto dokumenter pada proyek ini mengunakan teknik still life, maka penulis menggunakan kamera digital medium format 
dengan merek phaseone yang popular dalam pemotretan still life. Tujuannya adalah untuk menghasilkan gambar yang tetap natural dalam merepresentasikan wacana keseharian yang menjadi bentuk baru dalam realitanya, yang penulis bangun menjadi bentuk gambar kotak, mengikuti karakter kamera tersebut. Obyek obyek yang dibidik adalah benda yang ada di sekeliling bahkan keseharian manusia.

Objek foto dalam penelitian ini dibagi menjadi dua, yaitu benda-benda keseharian seperti sepatu, baju, kamera, alat-alat elektronik, perkakas lainnya yang berhubungan langsung dan memiliki kedekatan dengan penulis secara fungsional (objek pertama). Objek kedua adalah tembok, kusen jendela, pintu, langit-langit, dan lantai keramik.

Dari dua objek yang penulis kategorikan, dua objek tersebut memiliki pendekatan yang sama dalam membedah struktur dan super struktur dalam identitas penulis. Objek tersebut selanjutnya akan memiliki kecenderungan dalam memberikan penekanan sejauhmana identitas tersebut hadir dan berbaur. Hal ini penulis asumsikan sebagai ruang ketiga. Tantangannya adalah bagaimana menggambarkan struktur dan super struktur dalam bentuk foto. Maka dari itu, untuk menggambarkan struktur, penulis menganalogikan dengan objek bendabenda keseharian karena apabila merujuk pada pengertian apa itu struktur adalah sesuatu hal yang terkonstruksi langsung dan dapat dirasakan secara nyata. Objek kedua, yaitu tembok dan lainnya adalah bagaimana penulis menggambarkan super struktur. Apabila kembali pada pemahamannya, super struktur adalah sesuatu hal yang mempengaruhi penulis secara mendalam mengenai ideologi. Bila penulis menggambarkan dengan sudut tembok, kusen, dan lainya yang terkesan lebih abstrak.

\section{HASIL DAN PEMBAHASAN}

Hasil tulisan ini menjelaskan bagaimana peluang dalam pembacaan mengenai identitas dan kemungkinan mengenai ruang ketiga, seperti yang dijelaskan sebelumnya. Menurut Thomas Weski bahwa cara memilih dan membekukan sebuah citraan akan dunia realitas ke dalam sebuah gambar dengan latar gagasan artistik sebagai kerangka dalam konteks visual art. Thomas Weski memandang karya foto dalam koridor seni kontemporer di mana dalam karya-karya foto yang kini cenderung pada permasalahan makna 'teks' dan konsep, dari pada permasalahan foto itu sendiri. Fotografi dalam era kontemporer sudah tidak lagi membicarakan representasi, tetapi lebih jauh lagi, yaitu fotografi mempermasalahkan persoalan seperti layaknya sebuah karya seni pada umumnya. Hal ini menawarkan dan mengajak para pengamatnya untuk fokus pada subjek-subjek yang berbeda dengan sebuah cara pandang baru yang lebih terbuka (Demos, 2006: 7).

Tulisan ini berangkat dari kebaruan yang penulis tawarkan adalah sejauhmana penulis mengeksplorasi identitas personal yang menghadirkan "ruang ketiga" dalam kamar pribadi penulis. Penulis membagi dua kategori, yaitu foto yang mengambil berbagai sisi dari barang-barang keseharian yang berada di kamar kos penulis dan sudut-sudut kamar.

Penulis menyuguhkan bagaimana problematika keseharian tersebut dalam medium fotografi. Apa yang ada dalam kamar pribadi penulis, tanpa disadari adalah sebuah potret kehidupan modern saat ini. Dalam hal ini, bagaimana penulis melihat kamar pribadinya sebagai representasi dari identitas yang terbentuk karena struktur dan super struktur.

Untuk membaca karya ini, Perlu diperhatikan konsep struktur dan superstruktur. Struktur adalah sesuatu yang sudah melekat dalam diri penulis atau sesuatu yang dasar atau dalam konteks Ruang Keseharian Sebagai Representasi Identitas Personal adalah wilayah domestik yaitu kamar penulis, wilayah domestik yang ada dalam kamar kos. Penulis menganalogikan struktur tersebut dengan barang-barang pribadi penulis, apabila audience melihat foto tersebut dapat langsung berkonotasi kepada identitas penulis; siapa penulis, bagaimana gaya hidup penulis, dan dari mana kelas ekonominya. Sementara super-strukturnya adalah budaya, lingkungan, atau ideologi. Dalam super-struktur, penulis menganalogikan dengan sudut-sudut kamar, sudut kamar dikaburkan dengan pemaknaan tunggalnya, seperti halnya ideologi, budaya, dn lain-lian dll. Terkadang tidak bermakna tunggal dan bermacam-macam pemahaman, sama halnya dengan apa yang penulis lakukan dengan sudut-sudut kamar tersebut. Dengan mengaburkan makna sebenarnya mengenai sudut kamar tersebut, makna sudut kamar 
tersebut menjadi sesuatu yang melampaui sudut kamar itu sendiri.

Selain cara objek bekerja pada relasi index sebagai kerangka berpikir audience, penulis merelasikan keseharian yang tidak terduga tersebut dalam persentasi display. Dalam display, penulis tidak menyusunnya dengan beraturan, seperti pada umumnya foto seri dalam foto dokumnter tradisional. Akan tetapi penulis mengedepankan unsur 'instalasi', yaitu menyusun urutan seri foto tersebut dengan pendekatan yang tidak beraturan. Cara menyusunnya acak, ada yang saling menempel dengan foto lainnya dan ada pula yang terpisah, dari dua ukuran yang berbeda. Rasa keterkungkungan audience adalah tujuan utamanya agar index dalam memahami foto tersebut menjadi kabur, seperti halnya keseharian yang tidak dapat diduga dan tersembunyi 'di antara' baris-baris persepsi.

Unsur tidak terduga dalam melihat persoalan identitas dan ruang yang penulis eksplorasi, dalam Ruang Keseharian sebagai Representasi Identitas Personal adalah identitas yang terkonstruksi dari struktur dan super struktur. Maka dari itu penulis menggambarkan benda-benda keseharian yang setiap hari digunakan dan dilihat oleh penulis, serta bagaimana sudut-sudut kamar melengkapi dan memberikan ruang ketajaman dalam melihat identitas tersebut. Penulis 'merekayasa' tampilan dalam merepresentasikan bendabenda dan sudut kamar penulis. Yang dimaksud 'merekayasa' benda keseharian dan 'sudut kamar' dalam Ruang Keseharian sebagai Representasi Identitas Personal adalah motif kesenian. Tujuannya menghadirkan puitisasi, pelebihan, dan penerjemahan dari kebutuhan indrawi yang berakar pada kebutuhan biologis manusia. Alasannya, kebutuhan biologis manusia memiliki sensasi-sensasi yang sangat kuat, untuk mempertajam seleranya (Mondoki, 2007).

1. Benda-Benda Keseharian di Dalam Kamar

Gambar

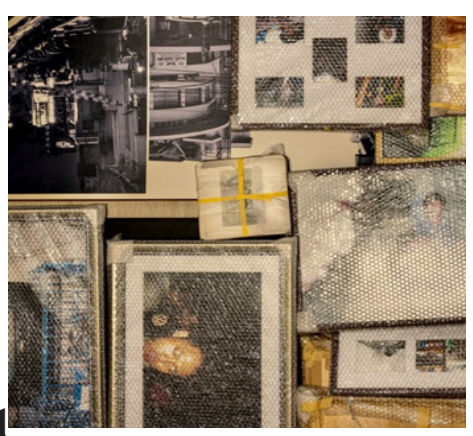

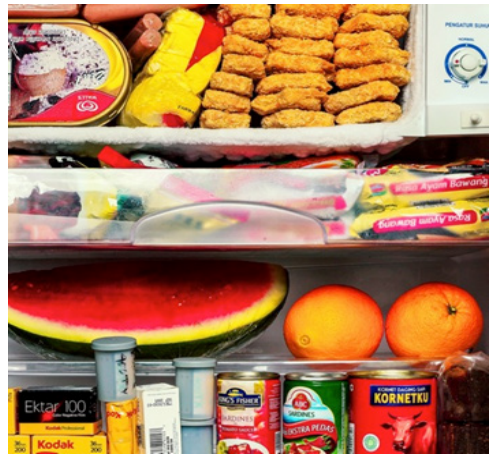

Gambar 2

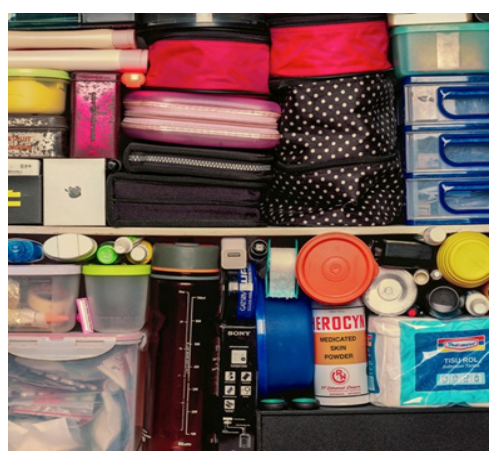

Gambar 3

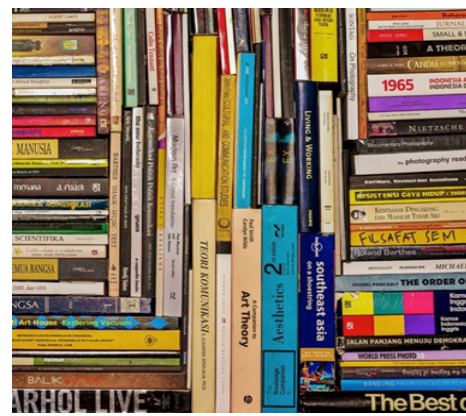

Gambar 4

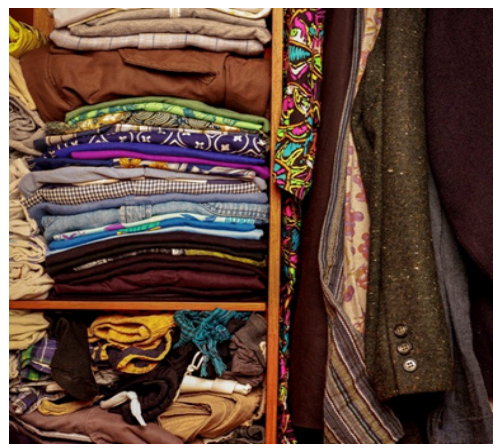

Gambar 5

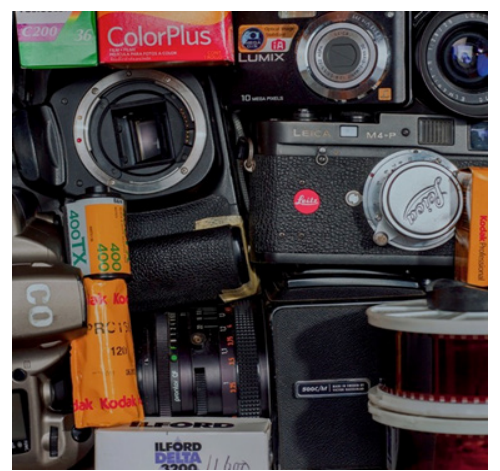

Gambar 6 


\section{Gambar 7}
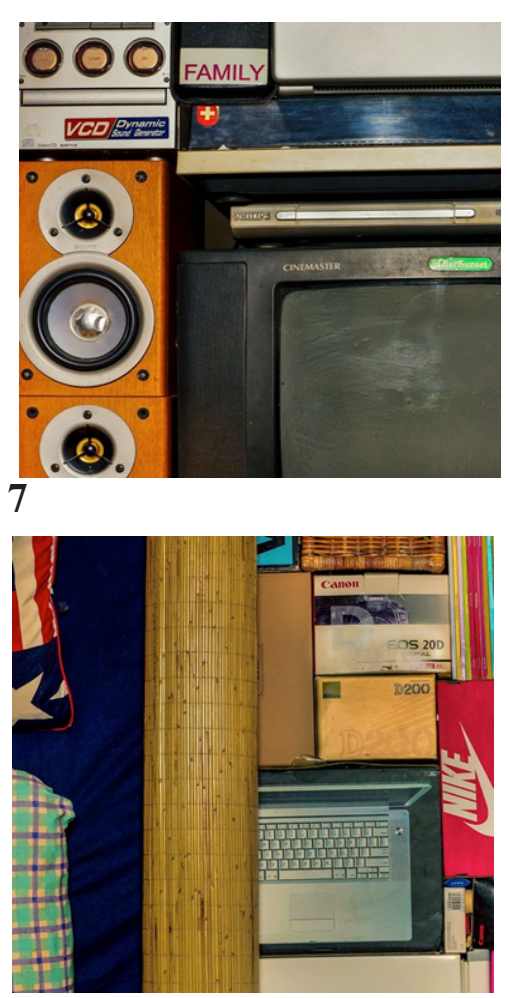

\section{Gambar 8}

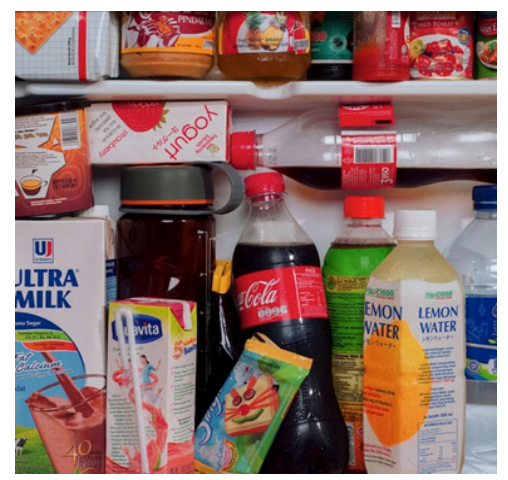

\section{Gambar 9}

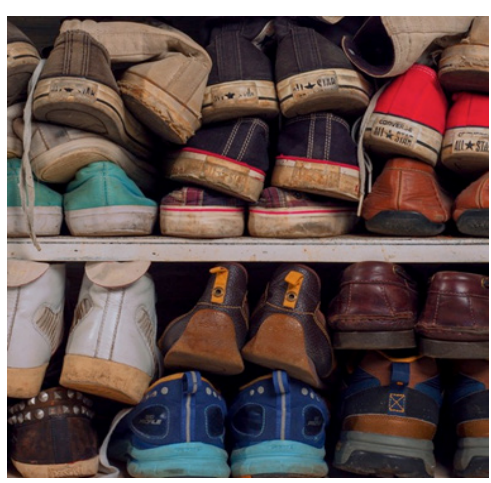

\section{Gambar 10}

Barang keseharian yang berada dalam kamar penulis adalah analogi dari struktur identitas yang melekat pada penulis. Penulis dengan sadar membeli dan mengkonsumsi seluruh produk tersebut. Hal ini pula yang dilakukan penulis dalam menyusun seluruh benda keseharian ini menjadi apa yang ada dalam foto di atas. Proses menyusun dilakukan dengan pendekatan spontan, tidak banyak menggunakan pertimbangan teori estetika.

Spontanitas dalam menyusun benda keseharian adalah refleksi dari sesuatu yang penulis lakukan dalam membeli produk tersebut. Tidak banyak pertimbangan, tetapi ada pengaruh alam bawah sadar kenapa penulis memutuskan membeli berbagai produk tersebut. Identitas dalam alam bawah sadar ini yang coba penulis ungkap agar audience mendapatkan kode-kode visual yang mandiri sesuai dengan pengalaman hidupnya.

Persoalan identitas adalah tema yang sering dipersoalkan oleh para seniman, baik seniman lokal dan mancanegara. Identitas dalam bendabenda keseharian yang penulis susun mengikuti rasa personal agar mampu menggambarkan sesuatu hal yang berbeda dari seniman-seniman sebelumnya. Penulis lakukan dalam merespon benda keseharian ini adalah dengan menyusun seluruh benda-benda dengan berbagai kategori. Kegiatan menyusun, memilih, dan menyatukan benda tersebut memiliki kecenderungan performatif dan jarang dilakukan senimanseniman Indonesia dalam mengungkap identitas pribadinya dengan medium fotografi.

Identitas penulis dalam benda keseharian ini pula yang memberikan pemahaman baru akan ruang dan benda keseharian. Bagaimana sebuah benda ditempatkan dan memberikan pemahaman baru akan identitas dan ruang. Produk-produk keseharian ini mampu menggambarkan siapa penulis sebenarnya, tetapi dengan ambiguitas bahwa tidak mudah memahami identitas penulis yang sebenarnya. Dengan penyusunan sedemikian rupa, benda keseharian tersebut memberikan dialog dan wacana baru yang penulis coba paparkan mengenai benda keseharian, ruang, dan identitas penulis.

\section{Sudut-Sudut Kamar}

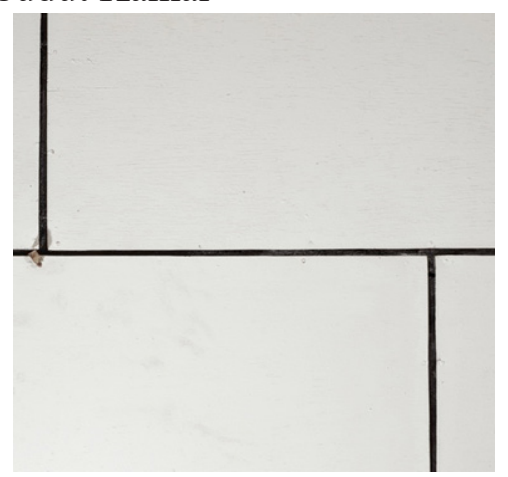

Gambar 11 


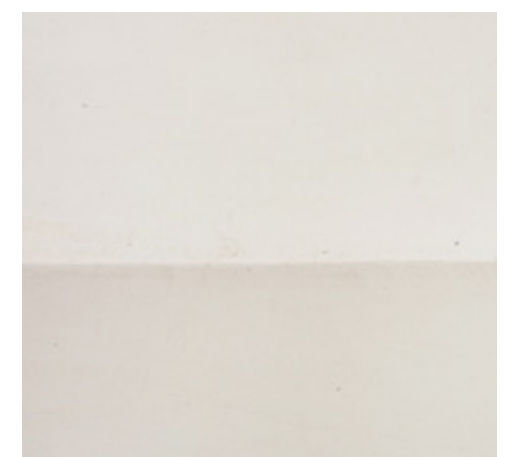

Gambar 12

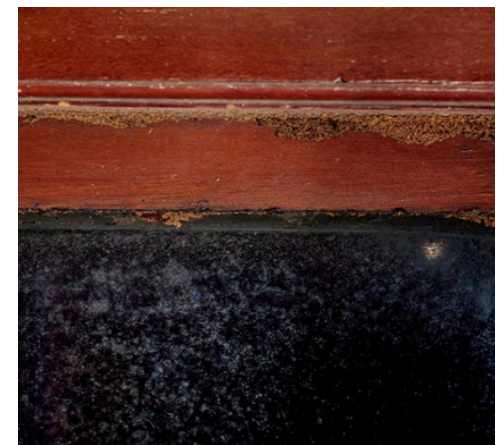

Gambar 13

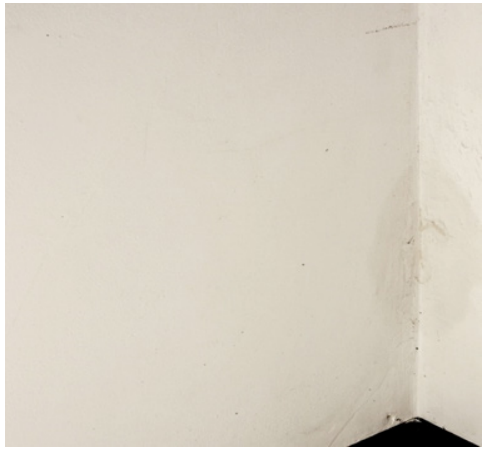

Gambar 14

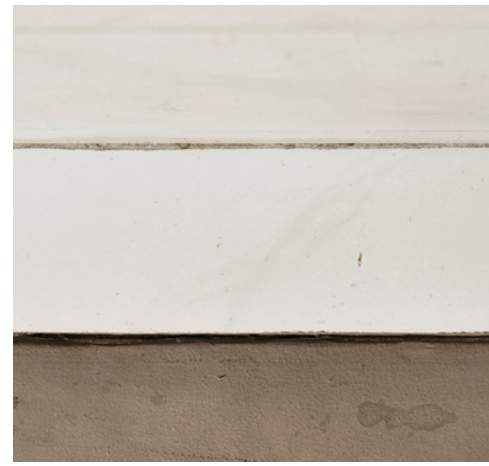

Gambar 15

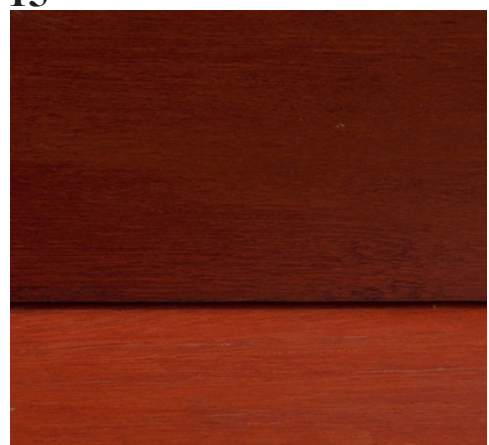

Gambar 16

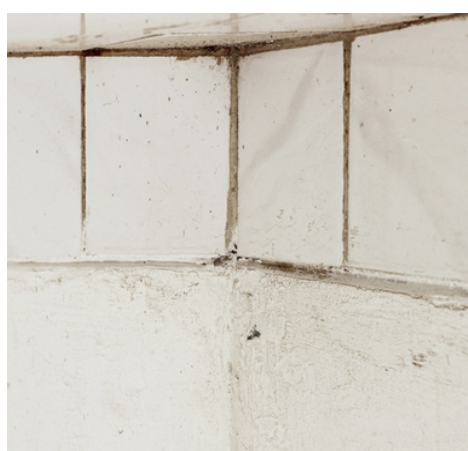

Gambar 17

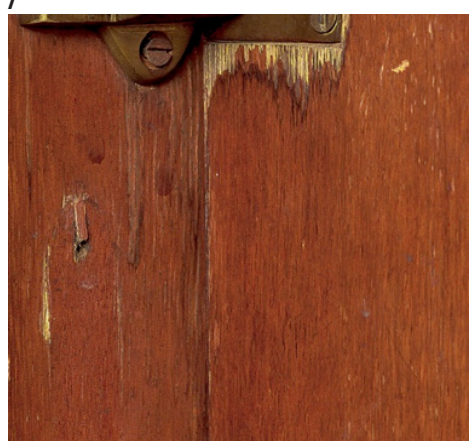

Gambar 18

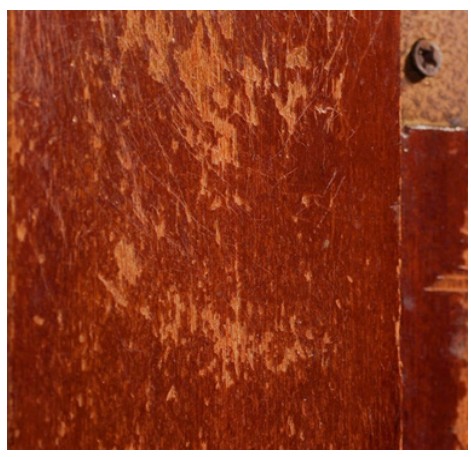

Gambar 19

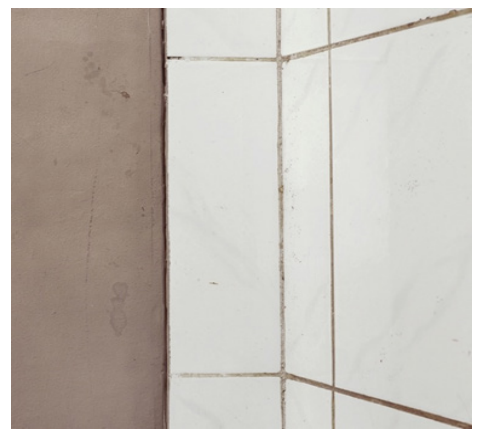

Gambar 20

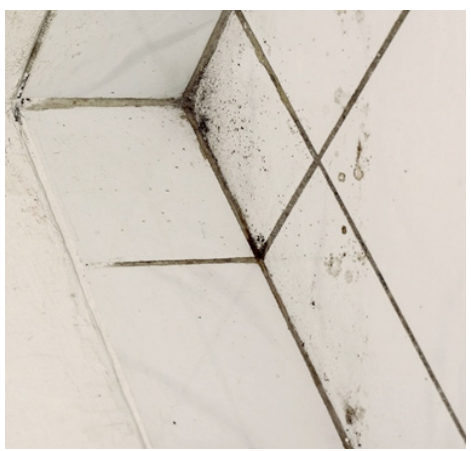

Gambar 21 


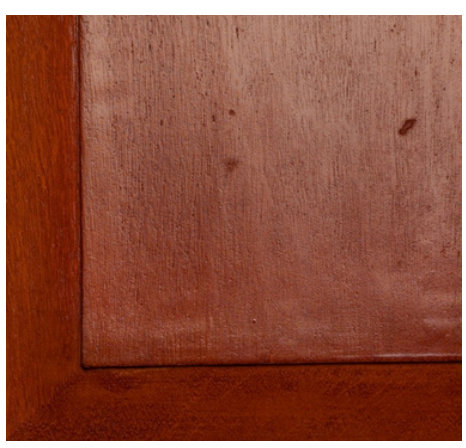

Gambar 22

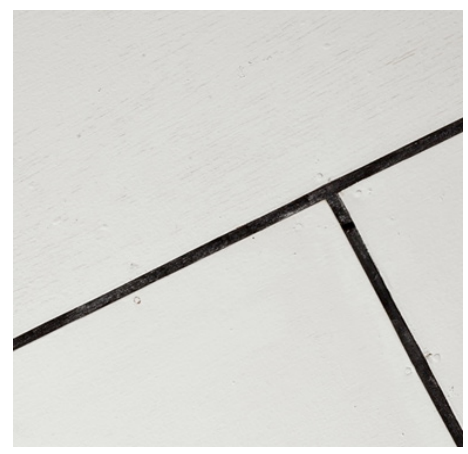

Gambar 23

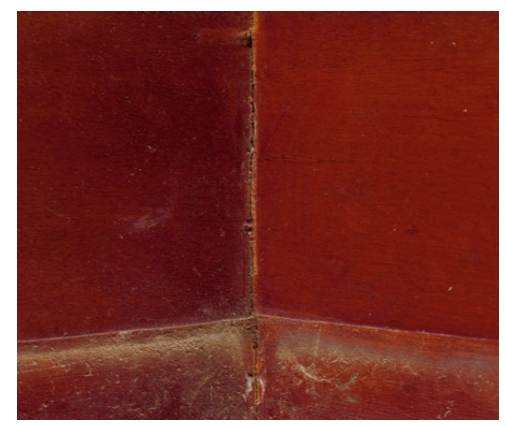

\section{Gambar 24}

Hubungan sudut kamar dengan identitas dan ruang adalah cara penulis menyimbolkan super struktur dalam tatanan semiotika postruktural. Dalam semiotika postruktural dinyatakan bahwa tanda tidak harus mengikuti struktur yang tetap. Hal ini menguatkan bahwa sudut kamar dapat menjadi sebuah tanda dari sebuah ruang yang membentuk identitas penulis, tetapi dapat berubah dalam prakteknya.

Persamaan antara benda-benda keseharian adalah paradoks karena tanda bersifat heterogen, plural, dengan kode-kode yang dramatis yang tidak mengikat. Dalam modernitas dan seni kontemporer, seniman dapat bermain-main dengan tanda selama tanda itu masih relevan. Dalam era kontemporer banyak riset yang mendukung hal tersebut.

Kegaduhanmelihatidentitas, diawalidengan perspektif posmodern yang mengasumsikan perbedaan identitas dalam waktu yang berbeda, identitas-identitas tidak disatukan secara koheren. Jadi menurut pandangan ini, terdapat identitas yang kontradiktif dan mempunyai aturan berbeda.

Sudut ruang dalam kamar penulis menggambarkan sisi esensial dalam diri penulis. Identitas esensialisme mengasumsikan bahwa di luar sana terdapat 'sesuatu' yang dapat ditemukan, bahwa identitas ada secara universal dan tidak terbatasi waktu.

Inti dari diri sendiri yang tidak terkecuali dimiliki oleh setiap orang. Dalam sudut kamar tersebut, ruang ketiga hadir yaitu tersebut menjadi legitimasi identitas yang membentuk ruang baru dalam ruangan yang sangat personal, yaitu kamar pribadi penulis. Ini adalah cara dalam mengartikulasikan dan mengungkapkan hal baru mengenai identitas personal dengan menghadirkan objek sudut-sudut kamar.

Setelah mengejawantahkan representasi Identitas personal dalam karya foto, maka cara menampilkan dalam ruang pamer adalah salah satu bagian utuh dari konsep representasi karya fotografi, seperti yang penulis pahami bahwa dalam fotografi dokumenter, cara menyusun atau memajang foto menjadi bagian dalam konsep karya yang utuh.

Dalam merepresentasikannya penulis mengunakan pendekatan 'instalasi' bukan pendekatan seri foto pada umumnya foto dokumnter tradisional yang disusun fotonya sesuai urutan foto. Dalam prosesnya tidak ada judul pada setiap foto, tapi hanya ada judul besar dan deskripsi. Foto dibagi menjadi dua ukuran, yaitu $100 \times 100 \mathrm{~cm}$ dan $50 \times 50 \mathrm{~cm}$, dengan tujuan sebagai representasi dari hapus penulis menggambarkan kedekatan pandangan dan keleluasaan pandangan.

Mendekat dan menjauh seperti halnya melihat keseharian yang terkadang dibutuhkan pandangan yang lebih luas dan lebih dekat, dengan tujuan bagaimana keseharian tersebut teridentifikasi dengan tepat, istilah fotografi hal ini disebut dengan istilah zoom in dan zoom out. Apabila soal format bentuk, yaitu kotak lebih mengikuti karakter dari kamera yang digunakan adalah kamera medium format. Secara keseluruhan, foto tersebut tidak memiliki judul atau keterangan gambar pada setiap fotonya karena foto tersebut saling berhubungan satu sama lain.

\section{Penampilan Karya dalam Ruang Pameran}




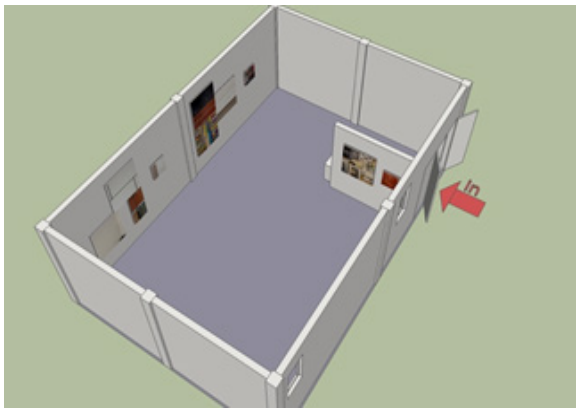

\section{Gambar 25}

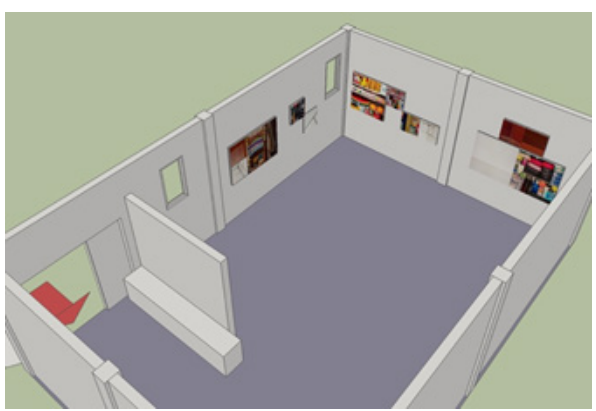

\section{Gambar 26}

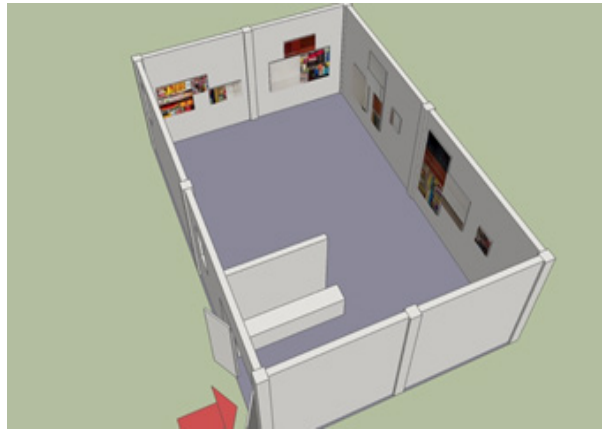

\section{Gambar 27}

\section{SIMPULAN}

Setelah menelusuri berbagai paparan di atas, maka terdapat tiga simpulan. Pertama medium fotografi adalah medium yang tepat untuk membedah keseharian karena unsur dalam keseharian sepenuhnya tidak rasional, maka mewacanakan keseharian secara rasional justru menghilangkan keunikan subtansi keseharian tersebut (Featherstone, 1995: 55). Dengan itu, medium fotografi yang memiliki sifat terlihat nyata sebagai perpanjangan ide. Oleh karena itu, fotografi sangat tepat digunakan sebagai medium representasi keseharian yang tidak rasional tersebut.

Kedua adalah identitas penulis terlihat nyata dan jelas, apabila dijelaskan menggunakan indeks yang ada dalam objek-objek keseharian tesebut, identitas keseharian dengan mengunakan pendekatan foto dokumenter begitu 'hidup'. Artinya pengertian, sebenarnya kita dapat melihat dari berbagai sisi serta dapat menampilkannya melalui sisi-sisi yang lain juga. Hal ini seperti cara menulis ini mencoba melihat sisi lain dari persoalan keseharian, terutama pada persoalan ruang personal. Dengan melakukan eksplorasi terhadap persoalan itu, penulis bukan hanya dapat melihatnya secara lebih luas, tetapi juga dapat melihat menyempitkan atau menyederhanakannya sehingga tampak persoalan yang sebelumnya luput dari pandangan diri sendiri.

Ketiga, bagaimana

penulis merepresentasikan Ruang Keseharian sebagai Representasi Identitas Personal. Dengan begitu tujuan pencapaian estetik dan bagaimana wilayah personal dapat direpresentasikan dengan tepat. Georg Simmel (1858-1918) berpendapat dalam menampilkan kembali narasi kecil atas kontruksi modernitas, maka keseharian modern dialami sebagai bombardemen sensoris yang agresif dan mengaburkan arah (disorienting). Kota adalah ruang yang dikelola dengan overstimulasi terhadap syaraf dan akhirnya cendrung menimbulkan respons kekerasan dan trauma terhadap kerumunan (agoraphobia). Maka dari itu hidup keseharian lantas merupakan masalah mampu tidaknya individu beradaptasi terhadap bombardemen sensoris itu (Simmel, 1971: 329). Ruang, keseharian, dan identitas bagi Benjamin adalah seperti masa lalu, masa kini, dan masa depan serta terpenting adalah kekinian dan dengan kesenian merupakan pengalaman yang diperkatakan dan direnungkan (Benjamin, 1982: 238).

\section{DAFTAR PUSTAKA}

Benjamin, W. (1982). Illuminations, trans. By Harry Zohn. London: Fontana

Demos, T. J. (2006). Vitamin Ph: New Perspectives in Photography. New York: Phaidon Press

Eriyanto. (2001). Analisis wacana: pengantar analisis teks media. Yogyakarta: LKiS

Featherstone, M. (1995). Undoing culture: globalization, postmodernization abd identity. London: Sage

Fiske, J. (2004). Cultual and communication studies: sebuah pengantar paling komprehensif. Yogyakarta: Jalasutra

Foucault, M. (1972). The archaeology of knowledge, Sheridan (terj.). New York: Pantheon

Katya, M. (2007). Everday aesthetics. Ashgate 
England.

Leach, N. (1997). Rethinking architecture: a reader in cultural theory. Routledge

Mahameruaji, J, N. (2014). Fenomena kontruksi identitas pada foto pra-wedding. Jurnal Kajian Komunikasi, Volume 2, No 1, 44-52.

Rayner, P. P. \& Stephen, K. W. (2001). Media studies: the essential introduction. New York: Routledge

Simmel, G. (1971). On individuality and social forms. Chicago: University of Chicago Press
Sukandar, A. (2001). Pemahaman ruang pusat jawa dari sudut konsep heteropia. Tesis, Program Magister Arsitektur, Institut Teknologi Bandung.

Sugiharto, B. (2013). Culture and everyday life. Bandung: Unpar

Sunardi, S.T. (2004). Semiotika negativa. Yogyakarta: Penerbit Buku Baik

Trifonas, P. P. (2003). Seri posmodern: barthes dan imperium tanda. Yogyakarta: Penerbit Jendela 